\title{
Who Wants to Save the Forest? Characterizing Community-Led Monitoring in Prey Lang, Cambodia
}

\author{
Nerea Turreira-García $\mathbb{D}^{1} \cdot$ Henrik Meilby $^{1} \cdot$ Søren Brofeldt ${ }^{1} \cdot$ Dimitris Argyriou $^{1} \cdot$ Ida Theilade $^{1}$
}

Received: 12 October 2017 / Accepted: 27 March 2018 / Published online: 6 April 2018

(C) The Author(s) 2018

\begin{abstract}
Community monitoring is believed to be successful only where there is sustained funding, legislation for communities to enforce rules, clear tenure rights, and an enabling environment created by the state. Against this backdrop, we present the case of an autonomous grassroots-monitoring network that took the initiative to protect their forest, in a context, where no external incentives and rule enforcement power were provided. The aim was to analyze the socio-demographic and economic backgrounds, motivations and achievements of forest monitors, compared to non-monitors in the same communities. A total of 137 interviews were conducted in four villages bordering Prey Lang forest in Cambodia. We used binary logit models to identify the factors that influenced the likelihood of being a monitor. Results show that there were few $(22 \%, n=30)$ active monitors. Active monitors were intrinsically motivated forest-users, and not specifically associated with a particular gender, ethnicity, or residence-time in that area. The most common interventions were with illegal loggers, and the monitors had a general feeling of success in stopping the illegal activities. Most $(73 \%, n=22)$ of them had been threatened by higher authorities and loggers. Our results show that despite the lack of power to enforce rules, absence of external funding and land-ownership rights, and enduring threats of violence and conflicts, autonomous community monitoring may take place when community members are sufficiently motivated by the risk of losing their resources.
\end{abstract}

Keywords Participatory monitoring $\cdot$ Community-based conservation $\cdot$ Natural resource management $\cdot$ Commons $\cdot$ Indigenous people $\cdot$ Collective action

\section{Introduction}

Nature conservation requires constant monitoring of the natural resources or ecosystems to be protected, which can be expensive and hard to sustain over time (Sheil 2001). Participatory approaches that include local stakeholders in natural resource monitoring have been presented as a costeffective solution to cover extensive areas over long periods of time (Moller et al. 2004; Danielsen et al. 2005; Takahashi and Todo 2012).

Locally based monitoring of illegal activities has proven effective to reduce poaching (e.g., de Merode et al. 2007; Dobson and Lynes 2008; Keane et al. 2011) and illegal

Nerea Turreira-García

ntg@ifro.ku.dk

n.turreira@gmail.com

1 Department of Food and Resource Economics, University of Copenhagen, Rolighedsvej 25, 1958 Frederiksberg, Denmark fishing (e.g., Petrossian 2015) all over the world. Local monitoring can especially help in conservation's blind spots, i.e., local people can contribute to prevent and control the unregulated exploitation within and outside formally protected areas (PAs), although this is seldom recognized by conservation professionals (Sheil et al. 2015). The benefits of local monitoring in forest condition have been shown to depend on well-defined boundaries of the resources, high level of forest-dependence, high social capital (Agrawal 2001), and rule enforcement power (Gibson et al. 2005; Chhatre and Agrawal 2008) among other factors.

Danielsen et al. (2008) categorized monitoring approaches based on the relative level of involvement of local people and professional scientists or experts: (1) externally driven and professionally executed; (2) externally driven with local data collectors; (3) collaborative monitoring with external data interpretation; (4) collaborative monitoring with local data interpretation and; (5) autonomous local monitoring. In categories 1-4, external actors play a decreasing role in design and execution of the monitoring 
activities, while the fifth category is defined by absence of external inputs.

Autonomous local monitoring is rarely present in the scientific literature due to its informal and independent nature; hence the results are rarely documented (Berkes 1999; Danielsen et al. 2008; Sheil et al. 2015). In spite of this, evidence exists that locally developed monitoring is a valuable complement to expert-based approaches (Moller et al. 2004; Danielsen et al. 2005). For example, hunters can provide observations of animal populations and help improve the regulations (Rist et al. 2009; Singh et al. 2014). Thus, local people may help achieve long-term nature conservation goals, as regular monitoring and sanctioning may lead to successful natural-resource management and protection (Ostrom 1990; Gibson et al. 2005; Takahashi and Todo 2012; Sheil et al. 2015).

However, when defining "local people", and often also "indigenous people", in the literature on successful management of commons, researchers tend to group together a large spectrum of socio-economic backgrounds, personal values, and behaviors toward nature. Not all individuals in a society, even in small-scale societies, necessarily share the common values of nature conservation (De Young 1993; DeCaro and Stokes 2008) or, as we hypothesize in this study, the willingness to monitor and actively protect the associated natural resources. Such values may be self-held or intrinsic beliefs, preferences, or concerns related to nature (DeCaro and Stokes 2008). For example, the willingness to "help the environment", socialize with people having similar interests, and learning about the environment have been shown to be important motivations to participate in environmental projects (Bruyere and Rappe 2007). Particularly, the sense of place (i.e., place attachment and place meaning) can be a motivation for stewardship and for taking action to care for the environment (Masterson et al. 2017).

Long-term conservation potential depends heavily on local people being motivated to commit their time continuously over several years (DeCaro and Stokes 2008; Garcia and Lescuyer 2008). Studies that have analyzed motivations to engage in nature conservation initiatives argue that commitment is more plausible when motivations are intrinsic, rather than extrinsic, i.e., when incentivized externally (De Young 1993; DeCaro and Stokes 2008; García-Amado et al. 2013). Intrinsic motivations are related to human core-values and attitudes toward nature (Chan et al. 2012, Raymond et al. 2013, Von Heland and Folke 2014), and may guide and constrain human actions (Folke et al. 2010, Adger et al. 2011, Berkes and Ross 2013). Extrinsic motivations may be monetary reinforcement, utilitarian interests, social recognition or pressure, fear, punishment, or legal mandates (De Young 1993; García-Amado et al. 2013). However, pre-existing intrinsic motivations are seldom studied in schemes that introduce other types of incentives, such as payments for ecosystem services (Rode et al. 2015).

The present study examined an autonomous network of forest-monitoring groups working across four provinces in Cambodia to investigate who the 'local people' that engage in community-led monitoring are and what motivates them to engage in a context where no external incentives are provided. We analyzed the (i) socio-demographic and economic backgrounds of people who engage in forest monitoring and people who do not; (ii) their motivations to engage in forest monitoring activities; and (iii) what their monitoring activities lead to including perceived results of the monitoring effort, feeling of success, and constraints to their work.

We use the terms monitoring and patrolling interchangeably, referring to the act of surveying the forest and recording data.

\section{Case Study}

This case study is based on the initiative of the Prey Lang Community Network (PLCN) to monitor their ancestral forests in the Central Plains of Cambodia, which can be characterized as community-led-and-executed monitoring [fifth category, according to Danielsen et al. (2008)]. In order to patrol and protect Prey Lang from deforestation, the self-organized forest monitoring network independently designed the monitoring scheme and carried out all information gathering and reporting of the gathered information. The case of PLCN was purposefully chosen as an example of an autonomous grassroots monitoring network that receives no external incentives and has no formal rule enforcement power.

Cambodia has the world's third highest national deforestation rate (Hansen et al. 2013), mainly driven by largescale acquisitions of land for agro-industrial purposes, primarily in the form of economic land concessions (ELCs) and mining concessions (Davis et al. 2015; Jiao et al. 2015; Work and Thuon 2017). These have led to a large scale agricultural conversion of forest land and extensive illegal logging operations outside the borders of the officially granted concession areas, which is in conflict with the land law, forestry law, and law on PAs. For further reading about Cambodia's politics of forest exploitation in the 1990s, see Le Billon (2000), Le Billon (2002), and Global Witness (2002), and for the 2000s, read Global Witness (2007) and Milne (2015). Since 1993, Cambodia's conservation strategies have focused on establishing PAs, but because of the poorly defined land and resource rights, weak governance and law enforcement, and the establishment of the PAs in populated areas of limited ecological significance, biodiversity conservation goals are not being met (Clements et al. 2010). 
Prey Lang forest covers around 530,000 ha in the central plains of the country, rendering it the largest lowland evergreen forest remaining in the Indochinese Peninsula. Prey Lang forest holds great ecological (Theilade et al. 2011; Hayes et al. 2015), economic (Jiao et al. 2015; Hüls Dyrmose et al. 2017), and cultural (Turreira-García et al. 2017) value.

The map in Fig. 1 shows Prey Lang (dark gray) situated within the four provinces, namely, Kampong Thom, Kratie, Stung Treng, and Preah Vihear with 52 communities having active members of the PLCN (white squares) and the 43 communities having no PLCN members (black diamonds).

Roughly 250,000 people live in Prey Lang and its surrounding areas. The majority of the population relies directly on the forest for their livelihoods, with resin extraction from dipterocarp trees being the main source of cash income for many (Hüls Dyrmose et al. 2017). Prey Lang is also a source of medicines, food, building materials, and firewood (Turreira-García et al. 2017). Access to natural resources is customary and without official property rights. The predominant ethnic groups are Kuy (indigenous) and Khmer (Cambodian). In Prey Lang both ethnic groups practice animism, and are culturally and spiritually linked to their forests (Turreira-García et al. 2017).

In May 2016, 432,000 ha of Prey Lang was declared as a "Wildlife Sanctuary" (Fig. 1). Before the establishment of the PA, Prey Lang was affected by 53 concessions, including roughly 50,000 ha of agro-industrial ELCs and mining concessions (Open Development Cambodia 2014). The concessions launder illegal timber from the surrounding areas destroying natural resources that much of the local population relies on (Forest Trends 2015). This has created a conflict between the local groups who want to protect the forest and the groups who derive income from timber extraction. Village headmen and local authorities, with vested economic interests in the logging industry, often use verbal and physical threats to hinder actions to stop illegal loggers (Milne 2015; Cultural Survival 2016).

The inhabitants of Prey Lang have traditionally patrolled the forest to protect resin trees and other natural resources. In the early 2000s, rampant illegal logging led some of the inhabitants to organize themselves into a forest monitoring group, called the PLCN. The PLCN advocates for forest protection and conservation through peaceful patrols and confiscation of logging equipment and illegally logged timber. Currently, the PLCN is not formally recognized by the Cambodian Government and has no rule enforcement or sanctioning power.

PLCN is organized into a steering committee (four people in 2015), a core group (20 people), and a group of ordinary members (about 500 people), all of whom are volunteers. The steering committee and the core members are selected through elections held in each province. The steering committee and the core group members organize meetings and patrols when someone warns of suspicious activity in the forest. The patrol groups vary in size and often consist of 15-20 people on motorbikes, covering various sections of the Prey Lang core zone as well as the major logging roads in and out of the area. Reports on illegal logging are filed and sent to authorities, the confiscated equipment is turned over to the authorities upon completion of the patrol, and the illegally cut timber is seized and burned on the site.
Fig. 1 Prey Lang forest (left) and its location in Cambodia (top-right). Forest-cover map modified from (Open

Development Cambodia 2014), economic land concessions and mining licenses data, taken from Licadho (2015)

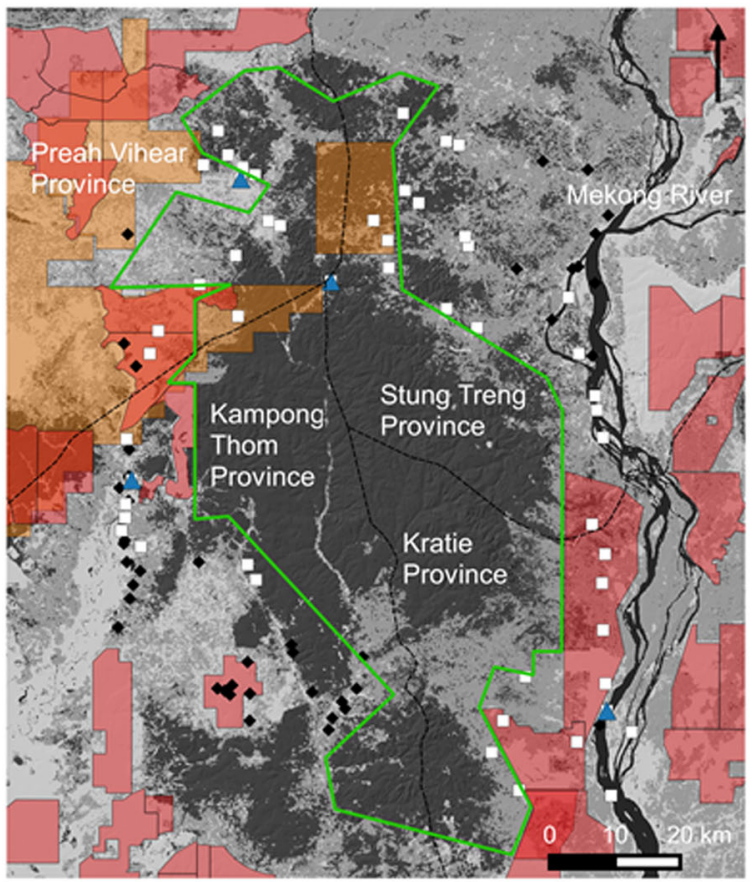

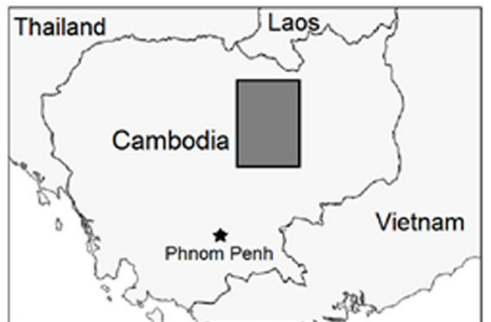

Legend

$\square$ Prey Lang Wildlife Sanctuary border $\square$ Dense forest $\square$ Mixed forest $\square$ Non-forest - Water

$\square$ Economic land concessions

$\square$ Mining concessions

-.-. Provincial border

- Villages No PLCN

Villages PLCN

$\Delta$ Fieldsites 


\section{Methods}

This mixed-methods study involved both members of the PLCN and a random sample of people from the general population in the villages surrounding Prey Lang. This composite sample allowed us to compare the sociodemographic and economic backgrounds, and the views of the co-inhabitants of a PA to ultimately characterize community-led forest monitoring in Prey Lang, Cambodia.

\section{Structured Interviews}

A structured interview was designed after conducting a workshop in August 2014 with the PLCN core group members, where they shared their experiences monitoring the forest: their history, current status, encounters, and motivations. Additionally, semi-structured interviews with the steering committee of the PLCN and NGOs that had collaborated in Prey Lang were used to gather background information about Prey Lang and the monitoring network. The questionnaire was pilot tested with two PLCN members.

A total of 137 structured interviews were carried out between January and May 2015. Interviews included both the members of PLCN and the non-members. First, we interviewed 21 PLCN members (18 men and 3 women) that attended the network's annual meeting in January 2015. Attendants came from villages of all four provinces of Prey Lang and every third person on the attendance list was selected for the interview. In the following months, we visited four villages and randomly selected from a list of villages where PLCN was active, one in each of the provinces where Prey Lang extends (Fig. 1, Triangles). In these villages, one person in every third household was interviewed regardless if they were members of PLCN or not, resulting in a total of 116 interviews (68 men and 48 women). To participate in the interview, the respondent had to be older than 16 years of age. In this way, we were able to get an overview of the representation and profile of the PLCN members, compared to the non-PLCN members in the selected villages. In the randomly selected villages, only two people declined to participate.

The first part of the interview dealt with the sociodemographic and economic background of the respondent and included the variables shown in Table 1. Gender, age, marital status, and ethnicity were variables also considered in Staddon et al. (2014). An interpreter asked the questions and translated the answers, which were recorded by the authors NTG and DA.

The second part of the interview focused on the participation in forest monitoring activities. Respondents were asked if they had ever heard of the PLCN and were they a member of it, were patrolling independently or were not involved in any form of patrolling. All members were interviewed about how often they participated, types of encounters in previous patrols, success in stopping illegal activities, and about threats and conflicts experienced.

Finally, all the respondents, whether members of PLCN or not, were asked if and why Prey Lang was personally important to them (open ended question).

\section{Ranking Exercise}

Among the 137 interviews, it emerged that 35 respondents were monitors (present and past), i.e., had regularly engaged in forest patrolling at some point in time. This sample included five monitors who were not actively monitoring the forest at the time of the study, but had done it in the past and could still relate to their motivations. The 35 monitors were requested to rank five pre-defined motivations for patrolling. The categories emerged from the discussion with PLCN core group members in August 2014 about their motivations to monitor the forest.

The motivation categories ranked were: "protect Prey Lang", "stop illegal activities", "report illegal activities", "collect natural resources" (monitors often collect rattan and vegetables, while undertaking monitoring activities), and "obtain economic revenue" (in the form of compensation provided by PLCN to cover travel and food costs). The categories captured particular functional distinctions and reflected the conceptual framework, described by GarcíaAmado et al. (2013): (1) the categories "protect Prey Lang" and "stop illegal activities" were included to reflect intrinsic motivations, (2) "report illegal activities" and "collect natural resources" to reflect utilitarian motivations, and (3) "obtain economic revenue" to reflect the monetary motivation. An option to mention any other motivation was also given. Finally, the respondents were asked if, in the hypothetical event, that an NGO hired him/her to patrol, the resulting economic revenue (wage) would change their ranking of the five motivation categories.

\section{Data Analysis}

We compared the socio-demographic and socio-economic backgrounds of members of PLCN against non-members to characterize people who show at least a nominal interest in forest protection. We further compared the active monitors against the non-active monitoring members of PLCN to characterize who was actively engaged in forest protection. Active monitors were defined as people who, at the time of the study, regularly participated in patrols. People who only participated occasionally and PLCN members who did not participate in monitoring were not regarded as active monitors in the analysis. 
Table 1 Variables obtained through the structured interview and summary of the data

\begin{tabular}{|c|c|}
\hline Variable & Specifications \\
\hline \multicolumn{2}{|l|}{ Socio-demographic variables } \\
\hline Gender $^{\mathrm{a}}$ & Males $(n=88)$; Females $(n=49)$ \\
\hline $\mathrm{Age}^{\mathrm{b}}$ & Age of respondent (years) \\
\hline Age class ${ }^{\mathrm{c}}$ & $\begin{array}{l}\text { Age class } 1(16-30 \text { years, } n=36) \text {; Age class } 2(31-40 \text { years, } n=37) \text {; Age class } 3(41-50 \\
\text { years, } n=35) \text {; Age class } 4(>50 \text { years, } n=29)\end{array}$ \\
\hline Married $^{\mathrm{a}}$ & Married $(n=118$ ); Unmarried (includes singles and widows, $n=19$ ) \\
\hline Kuy $^{\mathrm{a}}$ & Kuy $(1, n=46) ; \operatorname{Khmer}(0, n=91)$ \\
\hline Residence time $^{\mathrm{a}}$ & Native/Long-term resident ( $>10$ year of residence, $n=105$ ); Newcomer ( $\leq 10$ year, $n=32$ ) \\
\hline Member of PLCN ${ }^{\mathrm{a}}$ & Yes $(n=62) ;$ No $(n=75)$ \\
\hline \multicolumn{2}{|l|}{ Occupation related variables } \\
\hline Farmer $^{\mathrm{a}}$ & Respondent was a farmer $(n=130)$ or not $(n=7)$ \\
\hline Resin tapper ${ }^{\mathrm{a}}$ & $\begin{array}{l}\text { Respondent or household members extracted resin }(n=39) \text { or not }(n=98) \text {. Separated } \\
\text { from other NTFPs due to its high economic importance in Prey Lang }\end{array}$ \\
\hline NTFP collector ${ }^{\mathrm{a}}$ & Respondent collected NTFPs other than resin $(n=105)$ or not $(n=32)$ \\
\hline Businessman/woman ${ }^{\mathrm{a}}$ & Respondent or household members had a small shop or business $(n=66)$ or not $(n=71)$ \\
\hline Livestock owner ${ }^{\mathrm{a}}$ & $\begin{array}{l}\text { Respondent or household members raised domestic animals, sell them or spend time } \\
\text { walking the cattle }(n=116) \text { or not }(n=21)\end{array}$ \\
\hline Commune leadership group ${ }^{a}$ & $\begin{array}{l}\text { Respondent is a village headman, a commune advisor or a secretary }(n=6) \text { or not }(n= \\
131)\end{array}$ \\
\hline Seasonal worker ${ }^{\mathrm{a}}$ & $\begin{array}{l}\text { Respondent or household members worked temporarily in other farmer's fields and/or } \\
\text { resin trees, or sells seasonal fruits and vegetables to middle men }(n=104) \text { or not }(n=33)\end{array}$ \\
\hline \multicolumn{2}{|l|}{ Experiences } \\
\hline Types of encounters in patrols & $\begin{array}{l}\text { Illegal loggers (building a farm); Illegal loggers (working for a company); Timber left on } \\
\text { ground; Timber being transported; Sawing materials; Company overextending license; } \\
\text { Illegal fishing; Illegal mining; Illegal hunting; Company without license }\end{array}$ \\
\hline Freq. of encountering illegal activities & Few times; Often; In every patrol \\
\hline Success in stopping activities & Never; Occasionally; Always \\
\hline \multicolumn{2}{|l|}{ Perceived importance of the forest } \\
\hline Forest dependency $^{\mathrm{a}}$ & Mentioned the importance of its natural resources $(n=107)$ or not $(n=30)$ \\
\hline Environmental awareness $^{\mathrm{a}}$ & $\begin{array}{l}\text { Mentioned its environmental importance for current and future generations }(n=53) \text { or not } \\
(n=84)\end{array}$ \\
\hline Other $^{\mathrm{a}}$ & Mentioned other reasons $(n=32)$ or not $(n=105)$ \\
\hline Not important $\mathrm{t}^{\mathrm{a}}$ & Respondent did not consider Prey Lang as important $(n=13)$ or did $(n=124)$ \\
\hline Motivations & $\begin{array}{l}\text { Protect Prey Lang; Stop illegal activities; Report illegal activities; Collect natural } \\
\text { resources; Economic revenue }\end{array}$ \\
\hline
\end{tabular}

\section{${ }^{\mathrm{a} B i n a r y}$}

${ }^{\mathrm{b}}$ Continuous

${ }^{c}$ Ordinal variables

After evaluating all answers regarding the personal importance of Prey Lang, four main types of responses were identified: (1) because of its useful natural resources; (2) because of its environmental importance for current and future generations, (3) for other reasons and (4) the respondent did not consider Prey Lang as important. The third category included responses such as 'Prey Lang helps rice farming and forest gardening' and 'it is the legacy from our ancestors'. Each respondent could provide multiple reasons, and therefore the score in more than one category. In the analysis, the four response categories were represented by four binary variables: (1) forest dependency, (2) environmental awareness, (3) other, and (4) not important (Table 1).

Factors that influenced the likelihood of being a PLCN member were identified, using a binary logit model. The factors considered in the model included gender, marital status, age, ethnicity, residence time, occupation, and Prey Lang importance (see all variables in Table 1). A backward elimination approach was used to select the variables that were significant in the model (below the 5\% level). Nonsignificant variables were identified using Type 3 Wald 
chi-square tests and eliminated. The goodness-of-fit of all the binary logit models tested were compared using the loglikelihood, the Akaike Information Criterion (AIC), and the Schwarz Criterion (SC) of the models. For respondents who were members of PLCN, the same procedure was followed to build a binary logit model describing the probability of being an active monitor.

To analyze the data from the ranking exercise, each motivation category received a score expressing its perceived importance (score $=6-$ rank), upon which, the mean scores were calculated for each of the five motivation categories. These were then compared using the Kruskal-Wallis test and Wilcoxon's Signed Rank test.

\section{Results}

\section{Socio-demographic and Economic Backgrounds}

Of the 137 people interviewed, 62 were members of PLCN. A number of variables were found to characterize the members (Table 2): Firstly, non-timber forest product (NTFP) collectors had a higher likelihood of being members of PLCN than people who did not collect NTFPs. Secondly, compared to the oldest age class (Age class 4, >50 years) that acted as the reference class, people in age class 1
(16-30 years) had a significantly lower likelihood of being members, whereas people in age classes 2 and 3 (31-40 and 41-50 years, respectively) had a slightly higher likelihood of being members, which was significant for people in age class 3. Thirdly, married people had lower likelihood of being members of PLCN than people who were not married. Finally, people who did not mention Prey Lang as important had lower probability of being a member.

In total, 30 people were actively monitoring the forest at the time of the study. When analyzing what made a member of PLCN an active monitor, almost all of the variables included in the model (Table 1) turned out to be nonsignificant. Hence, the reduced model describing the likelihood of being an active monitor included only occupation and marital status (Table 3). Respondents could list more than one occupation, and it emerged that resin tappers and NTFP collectors were significantly more likely to be active monitors than people who were not resin tappers or NTFP collectors. By contrast, respondents who did some sort of business unrelated to natural resources had a significantly lower likelihood of being monitors than non-businessmen/ women. Similarly, people who considered themselves as farmers had a significantly lower likelihood of being monitors than non-farmers. Married PLCN members had a significantly lower likelihood of being active monitors than people who were not married.

Table 2 Parameter and odds ratio (OR) estimates for a binary logit model describing factors influencing the likelihood of being a member of PLCN. Model AIC $=178.3, \mathrm{SC}=198.8,-2 \log \mathrm{L}=164.3$, and $n=137$

\begin{tabular}{|c|c|c|c|c|c|}
\hline \multirow{2}{*}{$\begin{array}{l}\text { Parameter } \\
\text { Intercept }\end{array}$} & \multirow{2}{*}{$\begin{array}{l}\text { Estimate (SE) } \\
0.9772(0.6934)\end{array}$} & \multirow{2}{*}{$\frac{p \text {-value }}{0.1588}$} & \multirow{2}{*}{$\begin{array}{l}\text { OR estimate } \\
-\end{array}$} & \multicolumn{2}{|c|}{$\begin{array}{l}95 \% \text { Wald confidence } \\
\text { limits }\end{array}$} \\
\hline & & & & - & - \\
\hline NTFP collector & $0.8896(0.4733)$ & 0.0602 & 2.434 & 0.963 & 6.155 \\
\hline Age class 1 vs. 4 & $-1.3836(0.4431)$ & 0.0018 & 0.201 & 0.055 & 0.730 \\
\hline Age class 2 vs. 4 & $0.2580(0.3228)$ & 0.4241 & 1.035 & 0.368 & 2.914 \\
\hline Age class 3 vs. 4 & $0.9024(0.3448)$ & 0.0089 & 1.972 & 0.679 & 5.729 \\
\hline Married & $-2.0241(0.6973)$ & 0.0037 & 0.132 & 0.034 & 0.518 \\
\hline PL not important & $-1.9307(0.8577)$ & 0.0244 & 0.145 & 0.027 & 0.779 \\
\hline
\end{tabular}

Table 3 Parameter and odds ratio (OR) estimates for the binary logit model describing the effects of variables (Table 1) influencing the likelihood of being an active monitor among members of PLCN. Model AIC $=93.7, \mathrm{SC}=111.2,-2 \log \mathrm{L}=81.7$, and $n=62$

\begin{tabular}{llllr}
\hline Parameter & Estimate (SE) & $p$-value & OR estimate & 95\% Wald confidence limits \\
\hline Intercept & $-0.5280(1.2315)$ & 0.6681 & - & - \\
NTFP collector & $3.2051(1.3846)$ & 0.0206 & 24.657 & 1.634 \\
Resin tapper & $1.7603(0.6515)$ & 0.0069 & 5.814 & 1.622 \\
Businessman/Woman & $-2.2063(0.7174)$ & 0.0021 & 0.110 & 0.027 \\
Farmer & $-2.7948(0.9787)$ & 0.0043 & 0.061 & 0.009 \\
Married & $-1.9198(0.7247)$ & 0.0081 & 0.147 & 0.035 \\
\hline
\end{tabular}




\section{Motivation to Engage in Forest Monitoring Activities}

Respondents who had participated in commune-level patrols in the past or present $(n=35)$ were requested to rank five motivations for patrolling. The categories "protect Prey Lang" and "stop illegal activities" resulted in similar mean scores $(\mu=4.3$ and 3.8). According to many respondents, the protection of Prey Lang was synonymous with stopping illegal activities including incursions performed in relation to ELCs. For this reason, the two categories were interpreted as one in the analysis. "Receiving economic revenue" and "collecting NTFPs" were also grouped together $(\mu=1.9$ and 2.3$)$ and interpreted as motivations related to livelihood outcomes of monitoring.

A comparison of the resulting two overall motivation categories demonstrated that the motivations to protect Prey Lang had a significantly $(p<0.001)$ stronger association with participation in monitoring than other motivations related to livelihood outcomes of monitoring. In support of this, most respondents mentioned never obtaining any revenue from monitoring. The category "report illegal activities" did not seem to be a clear motivation for patrolling, as it was consistently ranked third $(\mu=2.7)$. A few monitors added "being happy living in Prey Lang", "loving nature", and "the protection of own land" as their second-most important motivation, but none of these were common. When asked if receiving a salary for monitoring would change their ranking, all respondents except two answered "No". Many of them gave statements such as "without Prey Lang there is no life".

The respondents who were not members of PLCN $(n=$ 75), 22\% $(n=16)$ had never heard about the monitoring network, even though they lived in villages where PLCN operates. People who knew of PLCN and were not members of it stated that the reason why they were not members was that they had never been invited, were busy with other activities, and/or had not received enough information about PLCN. Non-PLCN members did not patrol the forests on their own or with other groups.

\section{Perceived Value of the Forest}

In $78 \%$ of the interviews ( $n=107$ out of 137), Prey Lang was mentioned as important for wood to build traditional houses, resin trees for extraction of liquid (mainly) and solid resin, and other natural resources. Twenty-four percent ( $n$ $=33$ ) mentioned ecological functions of the forest, such as, regulating the rains, acting as a windbreak, preventing floods, storing carbon, and regulating the climate, $20 \%$ ( $n$ $=27$ ) mentioned the wellbeing of future generations, and 17\% $(n=23)$ explained that Prey Lang helps rice farming and forest gardening. As the question was open-ended, the respondents could mention more than one reason. Almost $10 \%(n=13)$ of the respondents did not mention a specific reason why Prey Lang was important, either because the forest was not important for them or because they had never reflected on it.

\section{Illegal Activities Reported by the Local Monitors}

The active members interviewed $(n=30)$ claimed that the most common encounters in past patrols were illegal loggers: $63 \%(n=19)$ of the respondents mentioned finding outsiders clearing the forest to establish farms and $60 \%$ ( $n$ $=18$ ) had encountered people clearing forest for a company. In addition, $43 \%(n=13)$ of the respondents had found $\operatorname{logs}$ left on the ground or logs that were being transported. Most of the respondents did not consider fishing $(87 \%, n=26)$ and hunting $(90 \%, n=27)$ as illegal. Licensed mining and other extractive activities were not considered illegal (Fig. 2).

The active members claimed that they were successful in stopping the illegal activities they encountered, either always $(55 \%)$ or occasionally (26\%). Monitors felt most successful in stopping illegal loggers working for a company (67\% of the times encountered) and clearing land for farms (47\% of the times). PLCN made written and verbal agreements with the perpetrators to stop logging in the future. Illegal timber left on site was most often burned (62\% of cases), and illegal timber being transported was most often confiscated (54\% of the times).

Most of the active monitors $(73 \%, n=22)$ had been threatened verbally by local authorities/police $(60 \%$ of the times). Threats were often of death, either targeting the monitor personally or his or her family members. At other times, monitors were threatened with imprisonment or had

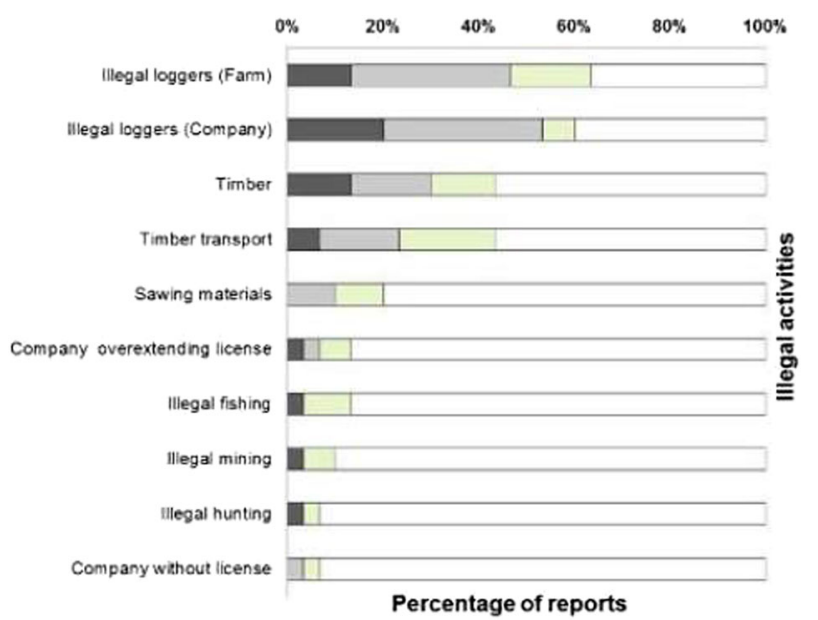

Fig. 2 Percentage of respondents reporting different illegal activities and the frequencies of these activities. The frequency categories were: in every patrol (dark), often (intermediate), few times (light), and never (white) 
guns pointed at them. In fewer instances, district or village headmen (13\%), forestry administration (FA) officials $(13 \%)$, or other local villagers and loggers $(13 \%)$ had persuaded respondents not to patrol. According to the monitors, the local authorities and other people in power, such as village headmen, have vested interests in illegal logging activities or are bribed to allow logging to take place. Seven monitors had experienced conflicts with other villagers when they burned illegal timber or confiscated chain-saws. In addition, $43 \%(n=13)$ of the active monitors had at some point been pressured by local authorities (police, village headmen, FA officials), and loggers not to report an illegal activity. Many respondents mentioned that they were frequently told by the local authorities that they did not have the right to patrol or confiscate materials.

\section{Discussion}

\section{Socio-demographic and Economic Background of Monitors}

The present case study shows that not all local people are willing to invest time and effort in actively trying to preserve the forest. We found that, although most of the individuals interviewed cared for the existence of the forest and the natural resources they can extract from it, active forest monitoring is the work of a relatively few dedicated individuals.

Members of PLCN, especially members taking part in forest patrols, were characterized as being forest-users. Irrespective of time of residence in the area, ethnicity and gender, a connection between livelihoods and forest resources, i.e., forest dependence, is a strong factor motivating forest-monitoring activities. For example, businessmen or businesswomen and farmers were less likely to participate in active monitoring.

Contrary to our results, a study from Nepal showed that gender influences monitoring, as men and women are differently involved in forest-related activities (Staddon et al. 2014). A study from Senegal argued that young people, women, and hierarchically "lower-ranking" ethnic groups participated less in politics (Crossouard and Dunne 2015). In partial agreement with this, young people were less commonly members of PLCN; however, ethnicity and gender did not significantly influence participation. Thus, these factors appear to be context-specific. Nevertheless, both the case of PLCN and the one presented by Crossouard and Dunne (2015) represent examples of how different segments of the society participate differently in processes that affect them all, be it deforestation, as in our case, or voting for presidential elections, as in their case. Although gender was not significantly associated with the likelihood of engaging in monitoring, we noticed that the representation of women among the monitors was lower than for men (27\% of members and $14 \%$ of active members were females). Women who engaged in monitoring were usually free of family burdens, either because they were young and not yet married, or because they had no small children. In addition, female participation was highest in a village where the provincial leader of PLCN was a woman and the core member of the village surveyed was also a woman. Hence, the study suggests that female leaders in the network can influence the participation of other women in forest monitoring positively, as also shown in other initiatives of female grassroots movements for urban governance in the Philippines, Nepal, and Uganda (Wyant and Spasić 2015).

Beyond socio-demographic and economic factors, in our view, the context in which monitoring occurs must be taken into account to understand the engagement in autonomous monitoring. In Cambodia, as well as elsewhere, people are likely to become 'activists' when they are directly affected by a conflict, as bottom-up monitoring groups are usually formed around a community-concern or a community need (Lawrence et al. 2005; Thornton 2013). In Cambodia, the community-concern or need is often the extraction of natural resources that are essential for the bio-cultural survival of forest-dependent people. This is because Cambodia is a highly biodiverse country with a very weak institutional conservation strategy (Clements et al. 2010) and uncontrolled illegal timber extraction, in which the government, the FA, and powerful tycoons are complicit (Global Witness 2002; Milne 2015). This makes local communities vulnerable and provokes them to act for themselves.

\section{Motivation to Engage in Forest Monitoring}

Despite continuous threats and intimidation, some local people are motivated to counteract illicit activities. When international conservation NGOs or governments are seen as remote institutions, local participants get motivated to take part in environmental conservation, as they see themselves as the only ones capable or willing to identify and resolve their concerns about the surrounding environment (Goodwin 1998; Savan et al. 2003). This has promoted the emergence of community-led monitoring in Prey Lang.

These motivations to engage in natural resource monitoring highlights a fundamental difference between externally driven monitoring [categories 1-4, according to Danielsen et al. (2008)] and completely autonomous monitoring [category 5]. In externally driven monitoring schemes, motivation is often linked to incentives offered to the communities or to the individuals involved. These incentives may be the ability for local participants to use the collected data for decisionmaking and management (Constantino et al. 2012; Boissière et al. 2013), recognition of tenure rights (Veer et al. 2006; 
Ruiz-Mallén et al. 2015), recognition of legal access (Van Rijsoort and Jinfeng 2005; Funder et al. 2013), and pecuniary benefits (Rode et al. 2015; Ruiz-Mallén et al. 2015). By contrast, autonomous monitoring can occur even if these benefits are not offered. In our case study, the autonomous PLCN was intrinsically motivated by protecting not only their natural resources, but the whole landscape, as it is an inherent part of their life and culture.

Similar to our case study, García-Amado et al. (2013) explained that when there were no payments for biodiversity and ecosystem conservation, in their case study in Mexico, intrinsic reasons for preserving nature (e.g., "because we should respect wild animals") clearly dominated over monetary or utilitarian motivations (e.g., "because it provides funds or allows us to have clean water"). However, their study also revealed that, as the number of years increased where payments were received, the weight of utilitarian and, especially, monetary motivations increased at the expense of intrinsic reasons. Participation in a community-led natural resource monitoring in Tanzania was sustained over time, because the local participants were driven by long-term and indirect benefits of monitoring, such as territorial and resource control, rather than by immediate economic incentives (Funder et al. 2013). Short-term economic incentives may not lead to sustained participation (Poulsen and Luanglath 2005; Staddon et al. 2015) and, therefore, externally incentivized monitoring schemes are more likely to be successful, where substantial intrinsic motivations for participation also exist.

Supporting the finding of Singh et al. (2014), who assessed the motivations of hunters to monitor moose populations over 26 years in Sweden, monitoring activities that are based on what the participants consider important makes engagement in monitoring rewarding in itself and therefore inherently sustainable. The only precondition for this is that, the communities are involved in defining monitoring objectives, which can happen in monitoring categories 3-5 of Danielsen et al. (2008).

The reluctance to report illegal activities might be related to mistrust in higher authorities, who are often involved in the illegal logging and do not recognize the work and rights of the monitoring network. Similarly, a case study from rural Australia showed that when land managers did not trust the authorities, they were less likely to report noncompliance with weed control (Graham 2014). The preference of PLCN to participating in patrols, rather than submitting reports to the authorities may also be linked to the feeling of success of the patrols and the lack of results from previous reporting to the authorities.

In addition to the motivation-categories included in our study, there might be other behavioral reasons to engage in patrols and, for example, other studies showed that a reputation of being trustworthy and more altruistic than others often motivates people to contribute for the public good (Ostrom 1998; Milinski et al. 2002; Barclay 2004). Yamagishi and Sato (1986) observed that different levels of cooperation in relation to use of public goods in Japan were affected by two types of motivation: greed (or desire to free ride) and fear (of being seen as a "sucker"). Greed was activated when the good was disjunctively produced and fear when it was conjunctively produced. This indicates that if forests or natural resources are seen as conjunctive goods, or commons, individuals would tend to cooperate (Ostrom 1990). However, our case showed that there are other elements, such as forest dependency and wanting to protect the territory from outsiders, which provide an additional motivation to actively engage in community-led forest monitoring.

\section{Perceived Results of Monitoring}

It is remarkable that, even though the active patrollers are relatively few and hold no sanctioning power or rule enforcement power, they perceive themselves to be successful in stopping illegal activities. This supports the theoretical assumption that customary access does not depend on coercive enforcement mechanisms (Ribot and Peluso 2009). In the case of weak or no institutional forest law enforcement, common in most Asian countries (Geist and Lambin 2002), local people tend to follow endogenous rules, rather than externally imposed rules (Clements et al. 2010).

Conflicts in relation to the timber industry are a daily concern in Cambodia, and it takes great courage by the active monitors to stand up in front of illegal loggers and corrupted authorities. Most monitors in Prey Lang relate similar accounts, as in other parts of Cambodia, where local people opposing illegal logging have experienced violent threats by government officials, armed forces, police, powerful businessmen, and employees (Milne 2015). Death threats and intimidation via phone calls are numerous. For example, interviewees frequently mentioned that "the authorities often remind us what happened to [the murdered environmental activist] Chut Wutty when they find us patrolling the forest".

\section{Conclusion}

While most studies have looked at benefits such as land titling and ownership as prerequisites for community-based monitoring to occur (Agrawal 2001; Danielsen et al. 2005), this study shows that autonomous community monitoring can occur in a context where secure land tenure does not exist, but with the expressed aim to protect the forest against illegal activities. 
We show that despite the lack of power to enforce rules and land-ownership rights, and enduring violent threats and conflicts, "local people" may commit to protect their environment over long periods of time. The autonomous environmental monitoring organization PLCN was characterized by volunteers that share a common concern about their environment. Participation in monitoring was associated with NTFP collection, age, marital status and perceived values in relation to the forest. Forest dependency and being married were found to increase the likelihood of actively engaging in locally-led monitoring of natural resources.

The autonomous forest monitoring network was led by a relatively small number of individuals and their main motivation to engage in monitoring was the intrinsic wish to protect their territory. Motivations are an important aspect to consider when developing participatory projects as they will determine the sustainability of the efforts over time (Singh et al. 2014). When involving local communities in externally-driven schemes, practitioners should consider how external incentives interact with the strength of 'intrinsic' motivation to participate over time.

Results show that local communities are heterogeneous in terms of interests toward environmental protection. Agrawal and Gibson (2001) argued that practitioners involving local communities in community-based resource monitoring and management should accommodate both internal-livelihoods, decision-making processes, age, gender, ethnicity-and external characteristics-interactions between the market, the state, and the community-of particular communities in their project designs. Additionally based on our results we recommend practitioners and community members that would like to work with environmental monitoring for nature protection to consider whether they would prefer to support the activity of individuals with substantial intrinsic motivation to participate or to recruit and motivate a broader subset of the community.

Local monitors considered illegal logging as the main threat to the forest and despite the adversities they considered themselves mostly successful in stopping illegal activities. Nevertheless, if monitors had sanctioning power, illegal logging in Prey Lang and other parts of Cambodia could decrease. Community members who find themselves in weak institutional situations, such as the PLCN, and that seek to escalate the impact of grassroots movements and achieve successful protection of the territories and related resources need positive institutional interactions (Gezon 1997; Persha et al. 2011; Graham 2014). These may be achieved by working together with other organizations, such as NGOs and Universities, which can help connecting local communities and policy-makers or governments and aligning the values and interests of each of the actors.

We recommend future monitoring programs and nature conservation initiatives, either externally-driven or community-led, to support and build on locally existing autonomous monitoring and protection activities. When initiatives are externally-driven we recommend bringing in locally perceived relevant incentives to ensure long-term participation, while also informing and involving local communities in global agendas to protect the environment. This would help operationalizing the principles of the Intergovernmental Science-Policy Platform on Biodiversity and Ecosystem Services, IPBES (and inherently the Convention on Biological Diversity) to complement and build upon existing initiatives relating to indigenous and local knowledge systems through participatory processes (IPBES 2016). We encourage more studies to investigate and document autonomous monitoring schemes in order to understand what motivates and sustain local peoples' engagement in environmental protection.

Acknowledgements We are grateful to all the people from Prey Lang who kindly allowed us to live with them and whom shared their experiences and time with us. Special thanks go to Narith Nou and Ernst Jürgensen from Danmission for their invaluable help. Finally we also wish to thank our interpreters Kim, Vuthy, Vannavy and Pengkhoan for their work. Thanks are due to DANIDA and Danmission for funding the project "Prey Lang-it's our forest too" (104. N.491.IP)

\section{Compliance with Ethical Standards}

Conflict of Interest The authors declare that they have no conflict of interest.

Ethical Approval "All procedures performed in studies involving human participants were in accordance with the ethical standards of the institutional and/or national research committee and with the 1964 Helsinki declaration and its later amendments or comparable ethical standards."

Informed Consent "Informed consent was obtained from all individual participants included in the study."

Open Access This article is distributed under the terms of the Creative Commons Attribution 4.0 International License (http://crea tivecommons.org/licenses/by/4.0/), which permits use, duplication, adaptation, distribution, and reproduction in any medium or format, as long as you give appropriate credit to the original author(s) and the source, provide a link to the Creative Commons license, and indicate if changes were made.

\section{References}

Adger WN, Barnett J, Chapin III FS, Ellemor H (2011) This must be the place: underrepresentation of identity and meaning in climate change decision-making. Glob Environ Polit 11:1-25. https://doi. org/10.1162/GLEP_a_00051

Agrawal A (2001) Common property institutions and sustainable governance of resources. World Dev 29:1649-1672. https://doi. org/10.1016/S0305-750X(01)00063-8

Agrawal A, Gibson CC (2001) Communities and the environment: ethnicity, gender, and the state in community-based conservation. 
Rutgers University Press, New Brunswick, New Jersey, and London

Barclay P (2004) Trustworthiness and competitive altruism can also solve the "tragedy of the commons. Evol Hum Behav 25:209-220. https://doi.org/10.1016/j.evolhumbehav.2004.04. 002

Berkes F (1999) Sacred ecology: traditional ecological knowledge and resource management. Taylor \& Francis, Philadelphia

Berkes F, Ross H (2013) Community resilience: toward an integrated approach. Soc Nat Resour 26:5-20. https://doi.org/10.1080/ 08941920.2012 .736605

Boissière M, Bastide F, Basuki I et al. (2013) Can we make participatory NTFP monitoring work? Lessons learnt from the development of a multi-stakeholder system in Northern Laos. Biodivers Conserv 23:149-170. https://doi.org/10.1007/s10531013-0589-y

Bruyere B, Rappe S (2007) Identifying the motivations of environmental volunteers. J Environ Plan Manag 50:503-516. https://doi. org/10.1080/09640560701402034

Chan KMA, Guerry AD, Balvanera P et al. (2012) Where are cultural and social in ecosystem services? A framework for constructive engagement. Bioscience 62:744-756. https://doi.org/10.1525/bio. 2012.62.8.7

Chhatre A, Agrawal A (2008) Forest commons and local enforcement. PNAS 105:13286-13291. https://doi.org/10.1073/pnas. 0803399105

Clements T, John A, Nielsen K et al. (2010) Payments for biodiversity conservation in the context of weak institutions: comparison of three programs from Cambodia. Ecol Econ 69:1283-1291. https://doi.org/10.1016/j.ecolecon.2009.11.010

Constantino P de AL, Carlos HSA, Ramalho EE et al. (2012) Empowering local people through community-based resource monitoring: a comparison of Brazil and Namibia. Ecol Soc. https://doi.org/10.5751/ES-05164-170422

Crossouard B, Dunne M (2015) Politics, gender and youth citizenship in Senegal: youth policing of dissent and diversity. Int Rev Educ 61:43-60. https://doi.org/10.1007/s11159-015-9466-0

Cultural Survival (2016) "Annexed": the rights of indigenous peoples in the Paris climate change talks. Cambodia: Help Prey Lang (“our forest”). Cult Surv Q Mag 40:3

Danielsen F, Burgess ND, Balmford A (2005) Monitoring matters: examining the potential of locally-based approaches. Biodivers Conserv 14:2507-2542. https://doi.org/10.1007/s10531-0058375-0

Danielsen F, Burgess ND, Balmford A et al. (2008) Local participation in natural resource monitoring: a characterization of approaches. Conserv Biol 23:31-42. https://doi.org/10.1111/j.1523-1739. 2008.01063.x

Davis KF, Yu K, Rulli MC et al. (2015) Accelerated deforestation driven by large-scale land acquisitions in Cambodia. Nat Geosci 8:772-775. https://doi.org/10.1038/ngeo2540

de Merode E, Smith KH, Homewood K et al. (2007) The impact of armed conflict on protected-area efficacy in Central Africa. Biol Lett 3:299-301. https://doi.org/10.1098/rsbl.2007.0010

De Young R (1993) Changing behavior and making it stick: the conceptualization and management of conservation behavior. Environ Behav 25:485-505. https://doi.org/10.1177/ 0013916593253003

DeCaro D, Stokes M (2008) Social-psychological principles of community-based conservation and conservancy motivation: attaining goals within an autonomy-supportive environment. Conserv Biol 22:1443-1451. https://doi.org/10.1111/j.15231739.2008.00996.x

Dobson A, Lynes L (2008) How does poaching affect the size of national parks? Trends Ecol Evol 23:177-180. https://doi.org/10. 1016/j.tree.2007.08.019
Folke C, Carpenter SR, Walker B et al. (2010) Resilience thinking: integrating resilience, adaptability and transformability. Ecol Soc. https://doi.org/10.5751/ES-03610-150420

Forest Trends (2015) Conversion timber, forest monitoring, and landuse governance in Cambodia. Forest Trends Report Series. http:// forest-trends.org/releases/uploads/Cambodia\%20Concessions\% 20Report\%20small\%20size.pdf. Accessed 26 Jun 2016

Funder M, Ngaga Y, Nielsen M et al. (2013) Reshaping conservation: the social dynamics of participatory monitoring in Tanzania's community-managed forests. Conserv Soc 11:218. https://doi. org/10.4103/0972-4923.121011

García-Amado LR, Ruiz Pérez M, Barrasa García S (2013) Motivation for conservation: assessing integrated conservation and development projects and payments for environmental services in La Sepultura Biosphere Reserve, Mexico, Chiapas. Ecol Econ 89:92-100. https://doi.org/10.1016/j.ecolecon.2013.02.002

Garcia CA, Lescuyer G (2008) Monitoring, indicators and community based forest management in the tropics: pretexts or red herrings? Biodivers Conserv 17:1303-1317. https://doi.org/10.1007/ s10531-008-9347-y

Geist HJ, Lambin EF (2002) What drives tropical deforestation? A meta-analysis of proximate and underlying causes of deforestation based on subnational case study evidence. Bioscience 52:143. https://doi.org/10.1098/rsbl.2008.0691

Gezon L (1997) Institutional structure and the effectiveness of integrated conservation and development projects: case study from Madagascar. Hum Organ 56:462-470

Gibson CC, Williams JT, Ostrom E (2005) Local enforcement and better forests. World Dev 33:273-284. https://doi.org/10.1016/j. worlddev.2004.07.013

Global Witness (2002) Deforestation without limits: how the Cambodian government failed to tackle the untouchables. A Report by Global Witness, July 2002. https://www.globalwitness.org/en/a rchive/deforestation-without-limits/. Accessed 14 Sep 2014

Global Witness (2007) Cambodia's family trees: illegal logging and the stripping of public assets by Cambodia's elite. A Report by Global Witness, June 2007. https://www.globalwitness.org/en/ reports/cambodias-family-trees/. Accessed 14 Sep 2014

Goodwin P (1998) "Hired hands" or "local voice": understandings and experience of local participation in conservation. Trans Inst $\mathrm{Br}$ Geogr 23:481-499

Graham S (2014) A new perspective on the trust power nexus from rural Australia. J Rural Stud 36:87-98. https://doi.org/10.1016/j. jrurstud.2014.06.010

Hansen MC, Potapov PV, Moore R et al. (2013) High-resolution global maps of 21 st-century forest conver change Science 342:850-853. https://doi.org/10.1126/science.1244693

Hayes B, Eang HK, Thy N et al. (2015) Biodiversity Assessment of Prey Lang: Kratie, Kampong Thom, Stung Treng and Preah Vihear Provinces. Phnom Penh, Cambodia

Hüls Dyrmose A-M, Turreira-García N, Theilade I, Meilby H (2017) Economic importance of oleoresin (Dipterocarpus alatus) to forest-adjacent households in Cambodia. Natural History Bulletin of the Siam. Society 62:67-84

IPBES (2016) Indigenous and local knowledge mandate. https://www. ipbes.net/indigenous-local-knowledge-mandate. Accessed 8 Nov 2017

Jiao X, Smith-Hall C, Theilade I (2015) Rural household incomes and land grabbing in Cambodia. Land Use Policy 48:317-328. https:// doi.org/10.1016/j.landusepol.2015.06.008

Keane A, Jones JPG, Milner-Gulland EJ (2011) Encounter data in resource management and ecology: pitfalls and possibilities. J Appl Ecol 48:1164-1173. https://doi.org/10.1111/j.1365-2664. 2011.02034.x

Lawrence A, Phillips OL, Ismodes AR et al. (2005) Local values for harvested forest plants in Madre de Dios, Peru: Towards a more 
contextualised interpretation of quantitative ethnobotanical data. Biodivers Conserv 14:45-79. https://doi.org/10.1007/s10531005-4050-8

Le Billon P (2000) The political ecology of transition in Cambodia 1989-1999: war, peace and forest exploitation. Dev Change 31:785-805. https://doi.org/10.1111/1467-7660.00177

Le Billon P (2002) Logging in muddy waters: the politics of forest exploitation in Cambodia. Crit Asian Stud 34:563-586. https:// doi.org/10.1080/1467271022000035938

Licadho (2015) Land concessions. Static maps and spatial data. http://www.licadho-cambodia.org/land_concessions/. Accessed 5 May 2016

Masterson VA, Stedman RC, Enqvist J et al. (2017) The contribution of sense of place to social-ecological systems research: a review and research agenda. Ecol Soc 22:1-15. https://doi.org/10.5751/ ES-08872-220149

Milinski M, Semmann D, Krambeck H-J (2002) Reputation helps solve the "tragedy of the commons. Nature 415:424-426. https:// doi.org/10.1038/415424a

Milne S (2015) Cambodia's unofficial regime of extraction: illicit logging in the shadow of transnational governance and investment. Crit Asian Stud 47:200-228. https://doi.org/10.1080/ 14672715.2015.1041275

Moller H, Berkes F, Lyver POB, Kislalioglu M (2004) Combining science and traditional ecological knowledge: monitoring populations for co-management. Ecol Soc 9:2

Open Development Cambodia (2014) Maps catalog, Forest cover map. https://opendevelopmentcambodia.net/layers. Accessed 17 May 2017

Ostrom E (1990) Governing the commons. The evolution of institutions for collective action. Cambridge University Press, New York, NY

Ostrom E (1998) A behavioral approach to the rational choice theory of collective action. Am Polit Sci Assoc 92:1-22

Persha L, Agrawal A, Chhatre A (2011) Social and ecological synergy: local rulemaking, forest livelihoods, and biodiversity conservation. Science 331:1606-1608. https://doi.org/10.1126/science. 1199343. (80-)

Petrossian GA (2015) Preventing illegal, unreported and unregulated (IUU) fishing: a situational approach. Biol Conserv 189:39-48. https://doi.org/10.1016/j.biocon.2014.09.005

Poulsen MK, Luanglath K (2005) Projects come, projects go: lessons from participatory monitoring in southern Laos. Biodivers Conserv 14:2591-2610. https://doi.org/10.1007/s10531-005-8390-1

Raymond CM, Singh GG, Benessaiah K et al. (2013) Ecosystem services and beyond: using multiple metaphors to understand human-environment relationships. Bioscience 63:536-546. https://doi.org/10.1525/bio.2013.63.7.7

Ribot JC, Peluso NL (2009) A theory of access. Rural Sociol 68:153-181. https://doi.org/10.1111/j.1549-0831.2003.tb00133.x

Rist J, Milner-Gulland EJ, Cowlishaw G, Rowcliffe M (2009) Hunter reporting of catch per unit effort as a monitoring tool in a bushmeat-harvesting system. Conserv Biol 24:489-499. https:// doi.org/10.1111/j.1523-1739.2010.01470.x

Rode J, Gómez-Baggethun E, Krause T (2015) Motivation crowding by economic incentives in conservation policy: a review of the empirical evidence. Ecol Econ 117:270-282. https://doi.org/10. 1016/j.ecolecon.2014.11.019

Ruiz-Mallén I, Schunko C, Corbera E et al. (2015) Meanings, drivers, and motivations for community-based conservation in Latin America. Ecol Soc 20:33. https://doi.org/10.5751/ES-07733200333
Savan B, Morgan AJ, Gore C (2003) Volunteer environmental monitoring and the role of the universities: the case of citizens' environment watch. Environ Manag 31:561-568. https://doi.org/ 10.1007/s00267-002-2897-y

Sheil D (2001) Conservation and biodiversity monitoring in the tropics: realities, priorities, and distractions. Conserv Biol 15:1179-1182. https://doi.org/10.1046/j.1523-1739.2001. 0150041179.x

Sheil D, Boissière M, Beaudoin G (2015) Unseen sentinels: local monitoring and control in conservation's blind spots. Ecol Soc 20:39. https://doi.org/10.5751/ES-07625-200239

Singh NJ, Danell K, Edenius L, Ericsson G (2014) Tackling the motivation to monitor: success and sustainability of a participatory monitoring program. Ecol Soc 19:7. https://doi.org/10.5751/ ES-06665-190407

Staddon SC, Nightingale A, Shrestha SK (2014) The social nature of participatory ecological monitoring. Soc Nat Resour 27:899-914. https://doi.org/10.1080/08941920.2014.905897

Staddon SC, Nightingale A, Shrestha SK (2015) Exploring participation in ecological monitoring in Nepal's community forests. Environ Conserv 42:268-277. https://doi.org/10.1017/ S037689291500003X

Takahashi R, Todo Y (2012) Impact of community-based forest management on forest protection: evidence from an aid-funded project in Ethiopia. Environ Manag 50:396-404. https://doi.org/ 10.1007/s00267-012-9887-5

Theilade I, Schmidt L, Chhang P, McDonald JA (2011) Evergreen swamp forest in Cambodia: floristic composition, ecological characteristics, and conservation status. Nord J Bot 29:71-80. https://doi.org/10.1111/j.1756-1051.2010.01003.x

Thornton JA (2013) Stakeholder participation in lake management in Wisconsin (USA). Lakes Reserv Res Manag 18:27-33. https:// doi.org/10.1111//re.12013

Turreira-García N, Argyriou D, Phourin C et al. (2017) Ethnobotanical knowledge of the Kuy and Khmer people in Prey Lang, Cambodia. Cambodian J Nat Hist 2017:76-101

Van Rijsoort J, Jinfeng Z (2005) Participatory resource monitoring as a means for promoting social change in Yunnan, China. Biodivers Conserv 14:2543-2573. https://doi.org/10.1007/s10531-0058377-y

Veer C, Muny M, Marschke M (2006) Community-based natural resource management in Cambodia: final review of IDRC supported initiatives and ideas for future programming; report of a mission. IDRC 1-103. https://www.academia.edu/32398818/ Community_based_natural_resource_management_in_Ca mbodia_final_review_of_IDRC_supported_initiatives_and_idea s_for_future_programming_report_of_a_mission. Accessed 20 Sep 2014

Von Heland J, Folke C (2014) A social contract with the ancestors: culture and ecosystem services in southern Madagascar. Glob Environ Chang 24:251-264. https://doi.org/10.1016/j.gloenvcha. 2013.11.003

Work C, Thuon R (2017) Inside and outside the maps: accommodating forest destruction in Cambodia. Can J Dev Stud. https://doi.org/ 10.1080/02255189.2017.1309313

Wyant R, Spasić K (2015) Grassroots women's accountability mechanisms: strengthening urban governance through organising and partnerships. Gend Dev 23:95-111. https://doi.org/10.1080/ 13552074.2015.1013677

Yamagishi T, Sato K (1986) Motivational bases of the public-goods problem. J Pers Soc Psychol 50:67-73 